\title{
Did UK scientist give France vital clues about H-bomb?
}

Paris. Historians reacted sceptically this week to controversial claims by a retired French weapons scientist that a British atomic scientist provided crucial information that helped France to explode its first hydrogen bomb in 1968.

Writing in La Recherche, the monthly science magazine, Pierre Billaud - who supervised the explosion of France's second H-bomb later the same year - asserts that the UK scientist approached André Thoulouze, the military attaché at the French embassy in London in 1967. The magazine identifies the scientist as Sir William Cook, Cook: identified as who was the head of possible contact. the British H-bomb project at Aldermaston in the 1950 s.

Billaud says that the scientist approached Thoulouze with the question "Your H-bomb, it's not coming along is it?" and later advised the French: "Don't look for complications. Try a simple design". According to Billaud, the British would have known that the French were pursuing the wrong course from analyses of fallout from atmospheric tests.

The UK scientist later gave Thoulouze other information, writes Billaud. Although no papers changed hands, this was sufficient to indicate to the French that they should use $\mathrm{X}$-rays from a fission device to compress the thermonuclear fuel and trigger fusion, instead of pursuing two more complicated options. At the same time, Billaud played down the importance of the British contribution, arguing that it allowed France to save two months at most, as trials of the Xray techniques were already planned.
But Lorna Arnold, official historian of the UK Atomic Energy Authority, says she is "sceptical" that Cook would have passed on such information. She argues that it would have been "inconceivable" for him to have done so without authorization from the government. And Britain would have been extremely unlikely to have acted without the blessing of the United States, she argues.

"Something doesn't add up," says Arnold, pointing out that, under a 1958 agreement with the United States, Britain was forbidden to pass information on nuclear matters to third parties. "There is something mysterious about [the claims]." Arnold's thinking is shared by André Finkelstein, a scientist at the French Atomic Energy Commission (CEA) who worked on the CEA archives before his retirement. He dismisses the possibility that Britain helped France as being without foundation.

Both speculate that the claims may be related to French political infighting as to who should receive credit for developing the $\mathrm{H}$-bomb. The most widely accepted version originates from statements by Alain Peyrefitte, General Charles de Gaulle's minister of research, and atomic and space affairs. Peyrefitte attributed the critical insight needed to develop the bomb to Roger Dautray, who was then a young physicist and is currently high commissioner of CEA.

Billaud's claims implicitly query Dautray's leading role, because they reaffirm comments made in 1984 by Jacques Chevallier - then head of CEA's military wing, DAM - that the major breakthrough was made by Michel Carayol, a young military engineer credited with recognizing the need for X-ray compression of the thermonuclear fuel.

Philippe Bergereau, a spokesman for CEA, says that the development of the French $\mathrm{H}$ bomb was "a team effort, and the paternity cannot be attributed to any individual".

Declan Butler

\section{Panel asked to rule on US-Indian patent row}

New Delhi. The United States has asked the World Trade Organization (WTO) to set up a panel to resolve a long-standing dispute with India about patents, following the failure of the two countries to reach agreement through bilateral talks. The dispute centres on India's refusal to give patent protection to pharmaceutical and agricultural chemical products.

When it joined the trade body in 1994, India promised to protect foreign drug patents by 2005 . But the United States and other countries want New Delhi to crack down sooner (see Nature

\section{New US air pollution regulations are set for a bumpy ride}

Washington. The scientific debate over the health effects of airborne particles and ground-level ozone is set to become more public and acrimonious following a proposal last week by the US Environmental Protection Agency (EPA) to tighten regulations on both pollutants.

The EPA's proposed rule would lower the standard for ozone from 0.12 parts per million (ppm) measured over a one-hour period to $0.08 \mathrm{ppm}$ over eight hours. It would regulate fine $(2.5$ microns and smaller) particles in the air for the first time, restricting their concentrations to 15 micrograms per cubic metre annually and 50 micrograms per cubic metre daily.

Both recommendations are based on controversial scientific evidence. The EPA's Clean Air Scientific Advisory Committee (CASAC), for example, concluded that, even though ozone causes adverse health effects, no 'bright line' distinguishes one proposed standard from another in terms of protecting public health.

The regulation of airborne particulates is even more fraught with uncertainty (see Nature 380, 11; 1996). CASAC only endorsed a 2.5-micron standard this year after much internal argument. The EPA says its recommendations are based on reviews of 271 scientific studies. But the in-house reviews, and the subsequent outside reviews by CASAC, were rushed because of a court order forcing the agency to propose a new regulation for particulates by 29 November.

The lack of scientific consensus is already being used as ammunition by industry groups opposed to tighter regulations. The new rules, if enacted, would probably force reduced emissions from cars, factories and utility companies, and would put hundreds of municipalities in breach of air pollution laws. The public, including scientific groups, will have 60 days to comment on the EPA proposal. The regulations would not come into force for at least five years.

Industry lobbyists fired the first salvo in the debate even before the agency went public with its new standards. The Air Quality Standards Coalition said that regulatory changes are "scientifically unjustifiable," and would "produce no significant improvement in public health".

Congressional opponents are likely to sound the same theme. During the last term, Congress voted itself the power to review specific government regulations as opposed to broad laws, and the new air pollution standards will be among the first tests of this new authority. And, unlike many of the environmental debates in the last Congress, serious scientists will be weighing in on both sides of this one.

Tony Reichhardt 